\title{
Zinc Seed Priming Improves Spinach Germination at Low Temperature
}

\author{
Muhammad Imran ${ }^{1,2}$, Asim Mahmood ${ }^{3}$, Günter Neumann ${ }^{3}$ and Birte Boelt ${ }^{1, *(D)}$ \\ 1 Department of Agroecology, Aarhus University, Forsøgsvej 1, 4200 Slagelse, Denmark; miguaf@gmail.com \\ 2 Nouryon, Velperweg 76, 6428BM Arnhem, The Netherlands \\ 3 Institute of Crop Science (340 h), University of Hohenheim, 70599 Stuttgart, Germany; \\ A.Mahmood@uni-hohenheim.de (A.M.); guenter.neumann@uni-hohenheim.de (G.N.) \\ * Correspondence: bb@agro.au.dk
}

Citation: Imran, M.; Mahmood, A. Neumann, G.; Boelt, B. Zinc Seed Priming Improves Spinach Germination at Low Temperature. Agriculture 2021, 11, 271. https:// doi.org/10.3390/agriculture11030271

Academic Editor: Alan G. Taylor

Received: 20 February 2021

Accepted: 17 March 2021

Published: 22 March 2021

Publisher's Note: MDPI stays neutral with regard to jurisdictional claims in published maps and institutional affiliations.

Copyright: (c) 2021 by the authors. Licensee MDPI, Basel, Switzerland. This article is an open access article distributed under the terms and conditions of the Creative Commons Attribution (CC BY) license (https:/ / creativecommons.org/licenses/by/ $4.0 /)$.

\begin{abstract}
Low temperature during germination hinders germination speed and early seedling development. Zn seed priming is a useful and cost-effective tool to improve germination rate and resistance to low temperature stress during germination and early seedling development. Spinach was tested to improve germination and seedling development with $\mathrm{Zn}$ seed priming under low temperature stress conditions. Zn priming increased seed $\mathrm{Zn}$ concentration up to 48 times. The multispectral imaging technique with VideometerLab was used as a non-destructive method to differentiate unprimed, water- and Zn-primed spinach seeds successfully. Localization of $\mathrm{Zn}$ in the seeds was studied using the 1,5-diphenyl thiocarbazone (DTZ) dying technique. Active translocation of primed $\mathrm{Zn}$ in the roots of young seedlings was detected with laser confocal microscopy. $\mathrm{Zn}$ priming of spinach seeds at $6 \mathrm{mM} \mathrm{Zn}$ showed a significant increase in germination rate and total germination under low temperature at $8{ }^{\circ} \mathrm{C}$.
\end{abstract}

Keywords: spinach; Zn priming; multispectral imaging; Zn localization; abiotic stress

\section{Introduction}

Spinach (Spinacia oleracea L.) is an annual crop, usually sown in early spring. Low soil temperature during early spring is one of the major factors affecting seed germination of various crops. In spinach, seed germination and early seedling establishment are inhibited at low temperature [1]. Imbibition and rehydration of dry seeds is a critical process during germination, and rapid absorption of water can cause severe membrane damage, leading to leakage of electrolytes, sugar, and amino acids [2]. Wuebker et al. [3] and Bochicchio et al. [4] reported embryo membrane damage, directly linked to the speed of imbibition at low seed moisture. Under low temperature conditions, these problems can be even more severe due to limited ability of cell membranes to maintain the integrity that is required during imbibition [5] and may compromise germination performance, leading to low germination rate, low uniformity, and final stand establishment. Spinach seeds germinate best between a range of temperatures between 15 and $24^{\circ} \mathrm{C}$. The germination speed and/or rate varies with the change in temperature. Germination speed is very slow at a temperature just above freezing. It may take up to three weeks for germination at $5{ }^{\circ} \mathrm{C}$, compared to one week at $20^{\circ} \mathrm{C}$.

Seed priming is a pre-sowing seed treatment, in which seeds are soaked in water and dried back to storage moisture contents for later use. According to Harris et al. [6], the 'on-farm seed priming' method has become very popular in developing countries. With the 'on-farm seed priming' method, seeds are soaked in a water or nutrient solution and air dried (not to storage moisture contents) prior to sowing. This can speed up germination, improve the tolerance to various stress conditions, and increase crop yield [7].

Chen and Arora [8] have proposed a hypothetical model demonstrating the cellular physiology of priming-induced stress-tolerance, likely achieved via two strategies. First, 
seed priming activates germination-related processes (e.g., respiration, endosperm weakening, and gene transcription and translation, etc.) that facilitate the transition of quiescent dry seeds into the germinating state, which improves germination potential. Secondly, priming imposes abiotic stress on seeds that repress radicle protrusion but stimulate stress responses (e.g., accumulation of Late Embryogenesis Abundant proteins (LEAs), potentially inducing cross-tolerance. The authors suggest that these two strategies constitute a "priming memory" in seeds, which mediates greater stress-tolerance of germinating primed seeds after the exposure to various stress conditions.

Stored reserves are the primary source of mineral nutrients during seed germination and early growth and should be adequate to sustain the seedling until the root system mediates nutrient uptake from the soil. Stored mineral nutrients are vital, particularly when seedlings are exposed to conditions of nutrient limitation [9]. In barley and wheat, seeds with low $\mathrm{Zn}$ contents showed delayed germination and poor seedling vigor, which negatively affected plant growth and final grain yield [10-12]. In wheat, seeds with high $\mathrm{Zn}$ concentrations produced better stand establishment, and seedlings were able to take up more $\mathrm{Zn}$ under $\mathrm{Zn}$-deficient soil conditions as compared to plants established from seeds low in Zn seed reserves [13]. During germination and early seedling development, particularly under stress conditions, micronutrients are essential. Zinc is a co-factor of various enzymes (superoxide dismutase (SOD)) involved in the detoxification of reactive oxygen species, such as $\mathrm{O}_{2}{ }^{-}$(superoxide radical) and $\mathrm{H}_{2} \mathrm{O}_{2}$ (hydrogen peroxide) [14]. $\mathrm{Zn}$ is directly involved in membrane stabilization, biosynthesis of auxins [15] and gibberellins [16] in plant growth regulation, and protein synthesis in general.

In "nutrient seed priming", seeds are soaked in a nutrient solution instead of pure water to improve seed nutrient contents in combination with the priming effect, which improves germination and seedling establishment. Ashraf and Rauf [17] found that priming maize seeds with $\mathrm{CaCl}_{2}$ improved final germination, rate of germination, and fresh and dry biomass of plumules and radicles, compared to untreated control and water-primed seeds under salt stress. Maize seed priming with $1 \% \mathrm{ZnSO}_{4}$ enhanced plant growth and increased final grain yield and $\mathrm{Zn}$ content of harvested seed from plants grown on soil with low Zn availability [18]. It has also been shown in maize [19] and rice [20] that primed $\mathrm{Zn}$ is translocated to growing shoots during germination and early seedling development. Furthermore, Imran et al. [21] also showed increased maize grain yield via $\mathrm{Zn}$ seed priming under low Zn-available soils combined with low temperature climatic conditions.

Based on the findings of seed priming memory in invoking seed stress tolerance [8] and the role of $\mathrm{Zn}$ seed priming in stress tolerance in crop plants, this study investigated the functions of water- and $\mathrm{Zn}$-priming of spinach seeds under low temperature. The multi-spectral imaging technique was used to monitor the $\mathrm{Zn}$ priming of spinach seeds, and confocal-laser microscopic analysis was performed to study $\mathrm{Zn}$ translocation in young spinach seedlings.

\section{Materials and Methods}

\subsection{Seed Material and Priming}

Commercially available spinach seed (Spinacia oleracea L. cv Matador) was obtained from the seed company Vikima Seeds A/S, Denmark. Seeds were primed for $24 \mathrm{~h}$ with water and $\mathrm{ZnSO}_{4} \cdot 7 \mathrm{H}_{2} \mathrm{O}$, according to Imran, Mahmood, Römheld, and Neumann [21], with some modifications, in which seeds after priming were surface dried at room temperature $\left(20^{\circ} \mathrm{C}\right)$ for $24 \mathrm{~h}$ before the germination test.

\subsection{Optimal Zn Concentration Levels for Seed Priming (Experiment 1)}

To determine the optimal $\mathrm{Zn}$ concentration for seed priming, $10 \mathrm{~g}$ of spinach seeds were soaked in $100 \mathrm{~mL}$ of $\mathrm{ZnSO}_{4} \cdot 7 \mathrm{H}_{2} \mathrm{O}$ solution. Concentrations of $\mathrm{Zn}$ in the priming solutions were e.g., 0 (deionized $\mathrm{H}_{2} \mathrm{O}$ ), 1, 2, 4, 6, 8, and $10 \mathrm{mM} \mathrm{Zn}$ solutions. Unprimed seeds were used as control treatment. A germination test of primed seeds was performed using the top of paper method at $12 \mathrm{~h}$ light and $12 \mathrm{~h}$ dark periods at $15^{\circ} \mathrm{C}$. Seeds were 
germinated in petri dishes with four replicates of 25 seeds per treatment. Seed germination data were recorded at Day 7 and Day 14 . The seeds with radicle protrusion $>2 \mathrm{~mm}$ were considered germinated.

\subsection{Germination Test of Water-and Zn-Primed Seeds at Low Temperature (Experiment 2)}

Based on the results of experiment 1, unprimed control, water-priming, and two levels of $\mathrm{Zn}$ concentrations were selected as seed treatments to test seed germination at two different temperatures, $8{ }^{\circ} \mathrm{C}$ (low temperature) and $15{ }^{\circ} \mathrm{C}$ (optimal temperature). The germination test was performed as mentioned above in experiment 1.

\subsection{Mineral Analysis of Seeds and Young Seedlings}

After the priming treatments, seeds were rinsed with deionized water for $1 \mathrm{~min}$ to remove any compounds and nutrients adhering to the seed coat before the analysis of seed mineral nutrients. Furthermore, mineral nutrients were also determined in young spinach seedlings. For this purpose, shoots and roots were separated in all treatments. To measure $\mathrm{Zn}$ concentration in seeds and seedlings, after drying at $65^{\circ} \mathrm{C}$, ground samples were ashed in a muffle furnace at $500{ }^{\circ} \mathrm{C}$ for $5 \mathrm{~h}$. After cooling, the samples were extracted twice with $2 \mathrm{~mL}$ of $3.4 \mathrm{M} \mathrm{HNO}_{3}(v / v)$ and subsequently evaporated to dryness. The ash was dissolved in $2 \mathrm{~mL}$ of $4 \mathrm{M} \mathrm{HCl}$, subsequently diluted 10-fold with hot deionized water, and boiled for $2 \mathrm{~min}$. After adding $0.1 \mathrm{~mL}$ of Cs/La buffer to $4.9 \mathrm{~mL}$ of ash solution, $\mathrm{Zn}$ and Mn concentrations were measured by atomic absorption spectrometry (UNICAM 939, Offenbach/Main, Germany).

\subsection{Confirmation of $Z n$ Accumulation in Spinach Seeds after $Z n$ Priming}

Staining of seed Zn was performed using 1,5-diphenyl thiocarbazone (DTZ), according to Ozturk et al. [22]. For this purpose, water- and $\mathrm{Zn}-(6 \mathrm{mM} \mathrm{Zn})$ primed seeds were incubated with $500 \mathrm{mg} \mathrm{L}^{-1} \mathrm{DTZ}$ at room temperature for $30 \mathrm{~min}$. The stained seeds were rinsed with deionized water and images were taken with a high-resolution digital camera. To determine the localization of primed $\mathrm{Zn}$ in the different seed tissues, fresh water and $\mathrm{Zn}$-primed ( $6 \mathrm{mM} \mathrm{Zn}$, rinsed with deionized $\mathrm{H}_{2} \mathrm{O}$ for $20 \mathrm{~s}$ ) seeds were immediately fixed in NEG $50^{\mathrm{TM}}$ gel. The fixed seeds were dissected to $20 \mu \mathrm{m}$ thick slices with a freezing microtome (MICROM HM 550, Microm International GmbH, Walldorf, Germany) and placed on microscope slides. Afterwards, $2 \mu \mathrm{L}$ of $500 \mathrm{mg} \mathrm{L}^{-1}$ DTZ solution was applied to the specimen to stain with $\mathrm{Zn}$. After $3 \mathrm{~min}$, a few drops of deionized $\mathrm{H}_{2} \mathrm{O}$ were applied before placing the coverslip on the thinly sliced sample. Photos were taken with a light microscope (Axiovert 200, Carl Ziess Microscopy GmbH, Göttingen, Germany).

To test the characteristic properties of the red color of DTZ stained spinach seeds (water- and Zn-primed), multi-spectral images of water- and Zn-primed seeds were taken according to Shrestha et al. [23]. Images from each seed sample were acquired using a VideometerLab instrument (Videometer A/S Herlev, Denmark). In this instrument, a topmounted camera acquires multispectral images with the help of 19 light emitting diodes (LEDs) at 19 wavelengths $(375,405,435,450,470,505,525,570,590,630,645,660,700,780$, $850,870,890,940$, and $970 \mathrm{~nm}$ ). Prior to image acquisition, the instrument was calibrated with respect to color, geometry, and self-illumination to ensure directly comparable images. After images were obtained, VideometerLab software (version 2.13.83) was used to extract and transform pixel data.

\subsection{Translocation of Primed $\mathrm{Zn}$ in the Roots of Spinach Seedlings}

The localization of $\mathrm{Zn}$ in the roots of 10-day old spinach seedlings was examined by using Zinpyr-1 $\left(\mathrm{C}_{46} \mathrm{H}_{36} \mathrm{Cl}_{2} \mathrm{~N}_{6} \mathrm{O}_{5}\right)$ fluorescence dye, according to Sinclair et al. [24]. For this purpose, unprimed, water- and Zn-primed $(6$ and $10 \mathrm{mM})$ spinach seeds were germinated in filter paper towels at $15^{\circ} \mathrm{C}$. Zinpyr- 1 was dissolved in dimethyl sulphoxide (DMSO) to make a $1 \mathrm{mM}$ stock solution and stored at $-20^{\circ} \mathrm{C}$. For root incubation, a working solution 
of $20 \mu \mathrm{M}$ Zinpyr-1 was prepared from the stock solution. From each treatment, 10-day old equally grown spinach seedlings were selected for Zinpyr-1 incubation.

Before immersing into a Zinpyr-1 working solution, seedlings were washed alternatively three times in deionized water and $10 \mathrm{mM}$ ethylene-diamine-tetra-acetic acid (EDTA). Seedlings were incubated in Zinpyr-1 solution for $5 \mathrm{~h}$ at room temperature in the dark. Afterwards, roots of the incubated seedlings were rinsed again in deionized water to remove the Zinpyr-1 dye from the root surface, immersed in $75 \mu \mathrm{M}$ propidium iodide to stain cell walls red, and rinsed again. For negative control, roots of water and Zn-primed seedlings were immersed in a Zn-chelator, $\mathrm{N}, \mathrm{N}, \mathrm{N}^{\prime}, \mathrm{N}$-tetrakis(2-pyridylmethyl) ethylenediamine (TPEN), for $30 \mathrm{~min}$. Samples were mounted in $0.9 \%$ saline, and images were taken on an Olympus (Hamburg, Germany) confocal laser-scanning microscope (CLSM), using excitation at $488 \mathrm{~nm}$ with a $100 \mathrm{~mW}$ Ar ion.

\subsection{Statistical Analysis}

Data on final germination were analysed by one-way analysis of variance (ANOVA) using SigmaStat 3.5 Software. Significant differences between the means were calculated at $p<0.05$ and marked with different letters.

Differences between means of $\mathrm{Zn}$ and Mn concentrations, reflectance, and speed of germination were compared using the standard error (SE) of four replicates ( 25 seeds in each replicate).

\section{Results}

\subsection{Optimal Zn Concentration}

At first count after 7 days (Figure 1a), seed germination performance was increased by all priming treatments, as compared to the unprimed control. Water-primed seeds showed $10 \%$ higher germination compared to the untreated control. However, at Day 7 , none of the Zn-priming and water priming treatments showed statistical difference in germination, but Zn-priming at $1 \mathrm{mM}, 6 \mathrm{mM}$, and $10 \mathrm{mM}$ had almost $22 \%, 20 \%$, and $18 \%$ higher germination, respectively, as compared to the unprimed control.

(a)

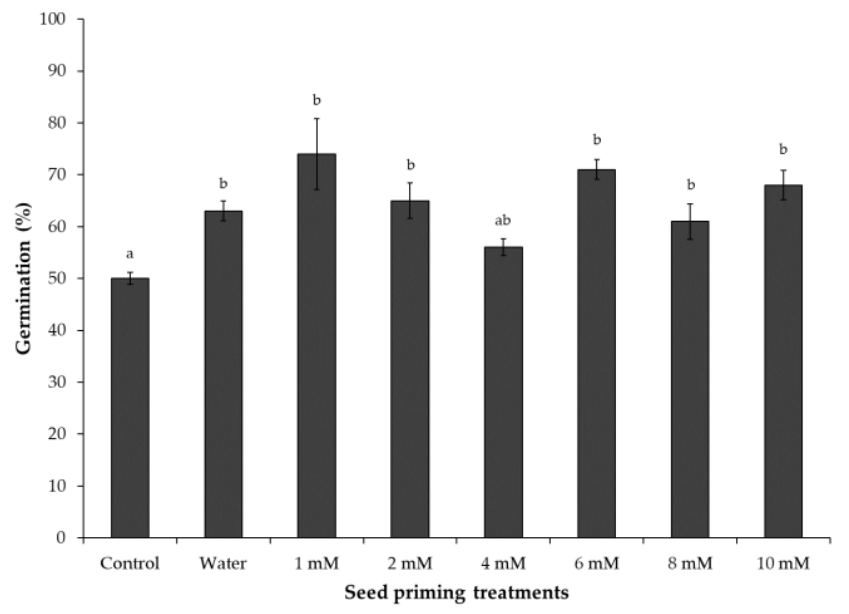

(b)

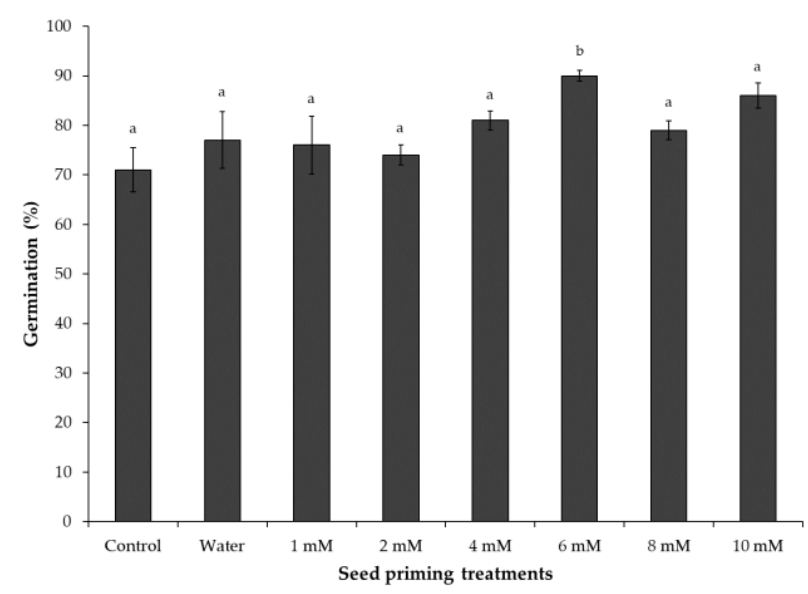

Figure 1. Germination percentage (\%) of spinach seeds at Day 7 (a) and Day 14 (b) after sowing on top of paper in Petri dishes at $15{ }^{\circ} \mathrm{C}$. Seed priming treatments included control (unprimed), water- primed, and Zn-primed at various $\mathrm{Zn}$ concentrations $(1,2,4,6,8$, and $10 \mathrm{mM} \mathrm{Zn)}$ in the priming solution. Bars represent the mean and standard error (SE) of four replicates (25 seeds in each replicate). Significant differences between the means were calculated at $p<0.05$ and marked with different letters.

At final count on Day 14 (Figure 1b), compared to the first count, differences in \% germination between unprimed, water-primed, and most of the Zn-priming treatments were not significant. Compared to other $\mathrm{Zn}$ priming treatments, priming at $6 \mathrm{mM} \mathrm{Zn}$ 
concentration showed significantly higher germination as compared with the control and water-primed treatments. Based on the results shown in Figure $1 \mathrm{~b}$, seed priming treatments at $6 \mathrm{mM}$ and $10 \mathrm{mM} \mathrm{Zn}$ concentrations, together with unprimed and water-priming, were selected for testing germination at a low temperature.

\subsection{Zinc Status of Seeds and Young Seedlings}

Zinc priming largely increased seed $\mathrm{Zn}$ concentration at $6 \mathrm{mM}$ and $10 \mathrm{mM}$ priming treatments compared to unprimed and water-primed treatments. There was approximately an increase of 30 and 48 times in seed $\mathrm{Zn}$ concentration, with $6 \mathrm{mM}$ and $10 \mathrm{mM}$ priming solutions, respectively, as shown in Table 1. Concentration of Mn was decreased up to $25 \%$ in seeds after $\mathrm{Zn}$ priming treatments but concentration of $\mathrm{Mn}$ in shoots and roots was not affected by $\mathrm{Zn}$ seed priming. Mineral analysis of shoots and roots of young spinach seedlings showed a 4 to 10 time increase in shoot and root $\mathrm{Zn}$ concentrations after both Zn-priming treatments compared to unprimed and water primed.

Table 1. Zinc and Mn concentrations in spinach seeds, shoots and roots of young seedlings after water, and Zn seed priming. Values represent the mean and standard error (SE) of four replicates.

\begin{tabular}{|c|c|c|c|c|}
\hline Treatments/Plant Parts & Unprimed & Water-Primed & $6 \mathrm{mM} \mathrm{Zn}$ & $10 \mathrm{mM} \mathrm{Zn}$ \\
\hline & \multicolumn{4}{|c|}{$\mathrm{Zn} \mu \mathrm{g} \mathrm{g}^{-1}$} \\
\hline Seeds & $56.2 \pm 0.1$ & $55.3 \pm 0.7$ & $1625.3 \pm 87.2$ & $2413.5 \pm 50.9$ \\
\hline Shoot & $163.6 \pm 0.8$ & $159.8 \pm 0.7$ & $522.2 \pm 14.4$ & $653.4 \pm 42.9$ \\
\hline \multirow[t]{2}{*}{ Root } & $85.2 \pm 2.8$ & $80.6 \pm 3.7$ & $603.2 \pm 11.5$ & $821.6 \pm 15.5$ \\
\hline & \multicolumn{4}{|c|}{$\operatorname{Mn} \mu g^{-1}$} \\
\hline Seeds & $45.1 \pm 1.8$ & $46.5 \pm 1.1$ & $36.5 \pm 0.9$ & $34.7 \pm 0.3$ \\
\hline Shoot & $45.7 \pm 0.3$ & $41.1 \pm 0.1$ & $46.6 \pm 0.3$ & $44.1 \pm 1.2$ \\
\hline Root & $31.9 \pm 2.1$ & $28.6 \pm 1.4$ & $26.3 \pm 0.5$ & $22.8 \pm 0.1$ \\
\hline
\end{tabular}

\subsection{Detection of Zn Primed Spinach Seeds with VideoMeter Lab and DTZ Staining}

To confirm the addition of $Z n$ in spinach seeds via $Z n$ priming, the DTZ staining method was used. Images of water-, $6 \mathrm{mM}$, and $10 \mathrm{mM}$ Zn-primed seeds (Figure 2a-c, respectively) showed no visible differences in all three treatments. Compared to normal images, multispectral images of the same samples taken with VideometerLab (Figure 2d-f), viewed at a wavelength of $700 \mathrm{~nm}$ in hot view mode, revealed more uniform and higher absorption of red color.

Higher development of red color in 6- and 10-mM Zn-primed seeds after DTZ staining indicates a higher level of $\mathrm{Zn}$ compared to water primed seeds. Differences in the mean spectrum of DTZ stained water- and Zn-primed seeds are shown in Figure 3.

Other spectrum characteristics data (Table 2), such as CIELab, intensity, hue, and saturation, also revealed the development of a darker red color in $\mathrm{Zn}$-primed seeds after DTZ staining, as compared to water priming.

Table 2. Characteristic color parameters: CIELab L, intensity, hue, and saturation of DTZ-stained spinach seeds after water-, $6 \mathrm{mM}$, and $10 \mathrm{mM}$ Zn-priming. Values represent the mean and standard error (SE) of four replicates. Significant differences between the means were calculated between seed priming treatments at $p<0.05$ and marked with different letters.

\begin{tabular}{ccccc}
\hline Priming Treatments & CIELab L & Intensity & Hue & Saturation \\
\hline Water-primed & $62.2 \pm 0.9 \mathrm{a}$ & $29.3 \pm 1.0 \mathrm{a}$ & $140.2 \pm 0.4 \mathrm{a}$ & $18.8 \pm 0.7 \mathrm{a}$ \\
$6 \mathrm{mM} \mathrm{Zn}$ & $55.7 \pm 0.7 \mathrm{~b}$ & $22.8 \pm 0.6 \mathrm{~b}$ & $134.7 \pm 0.4 \mathrm{~b}$ & $16.1 \pm 0.6 \mathrm{~b}$ \\
$10 \mathrm{mM} \mathrm{Zn}$ & $53.9 \pm 0.9 \mathrm{~b}$ & $21.4 \pm 0.7 \mathrm{~b}$ & $133.9 \pm 0.4 \mathrm{~b}$ & $15.7 \pm 0.7 \mathrm{~b}$ \\
\hline
\end{tabular}



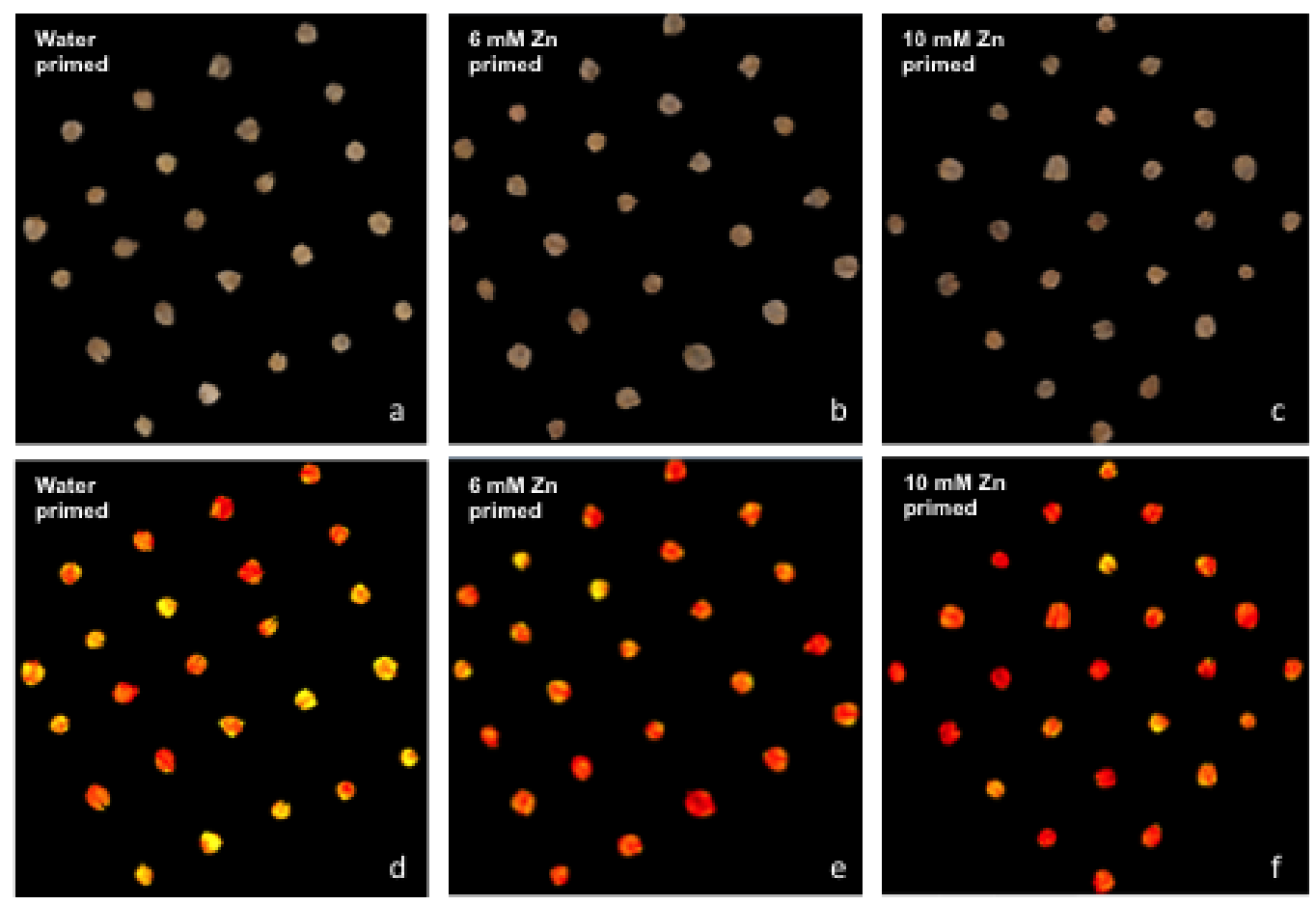

Figure 2. Visible spectrum images of 1,5-diphenyl thiocarbazone (DTZ)-stained water (a), $6 \mathrm{mM}$ (b), and $10 \mathrm{mM}$ (c) Zn-primed seeds. Images (d-f) (water-, $6 \mathrm{mM}$, and $10 \mathrm{mM}$ Zn-primed seeds, respectively) taken with VideometerLab at wavelength $700 \mathrm{~nm}$ in hot view mode.

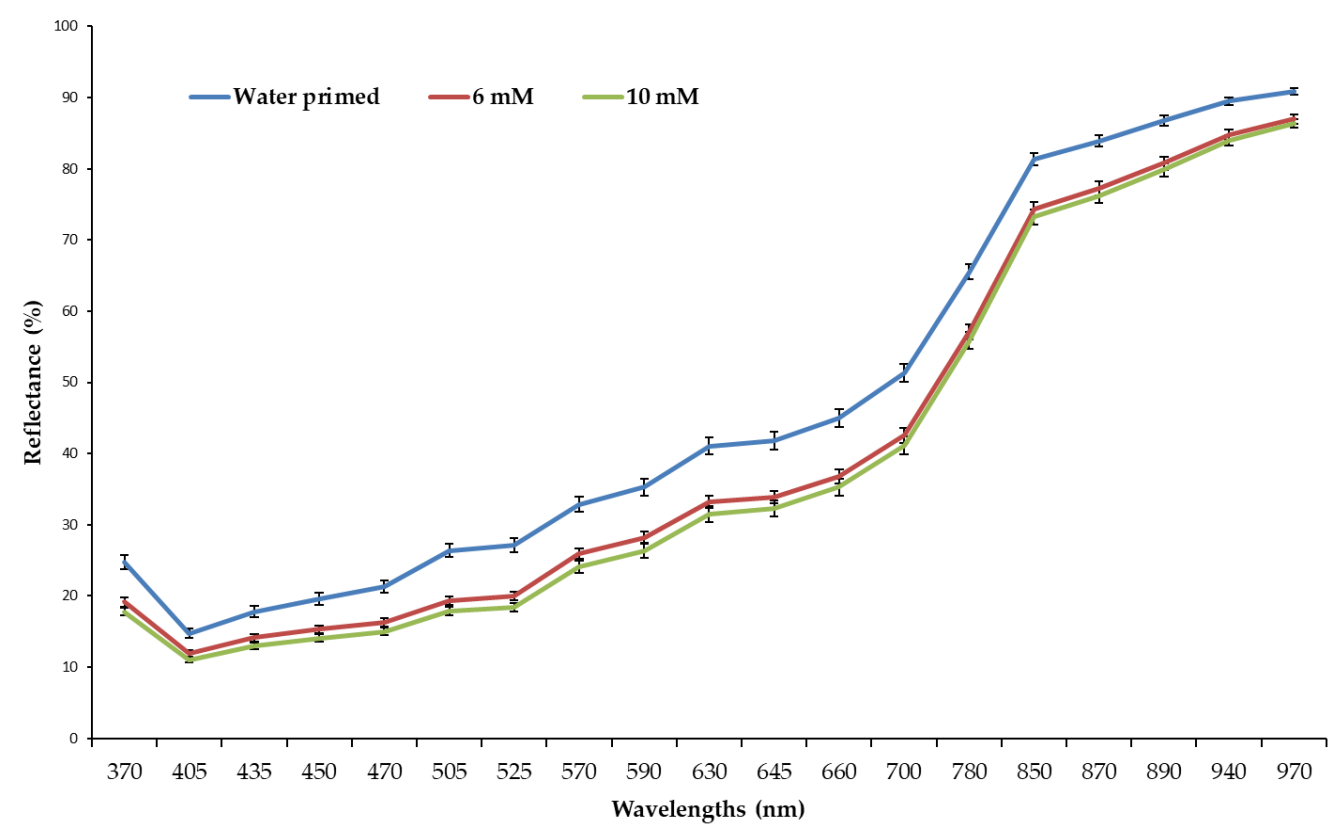

Figure 3. The mean visible spectrum of water-, $6 \mathrm{mM}$, and $10 \mathrm{mM} \mathrm{Zn-primed} \mathrm{spinach} \mathrm{seeds} \mathrm{extracted} \mathrm{from} \mathrm{the} \mathrm{multi-spectral}$ images of seeds at 19 wavelengths $(375,405,435,450,470,505,525,570,590,630,645,660,700,780,850,870,890,940$, and $970 \mathrm{~nm}$ ). Bars represent the mean and standard error (SE) of four replicates ( 25 seeds in each replicate).

\subsection{Zinc Localization in the Roots of Spinach Seedlings}

Laser confocal microscopy was employed to detect $\mathrm{Zn}$ (in vascular tissues) in the roots of 10-day-old spinach seedlings, germinated from water-, $6 \mathrm{mM}$, and $10 \mathrm{mM} \mathrm{Zn-primed}$ seeds, (Figure 4a,b). Higher intensities of Zinpyr-1 fluorescence in $6 \mathrm{mM}$ and $10 \mathrm{mM}$ (Figure $5 \mathrm{~d}$,e, respectively) compared to unprimed and water-primed seedlings (Figure 5a,b, 
respectively) indicates higher accumulation of $\mathrm{Zn}$ in the roots of $\mathrm{Zn}$-primed seedlings compared to water-primed seedlings, irrespective of $\mathrm{Zn}$ concentration in Zn-primed seeds.

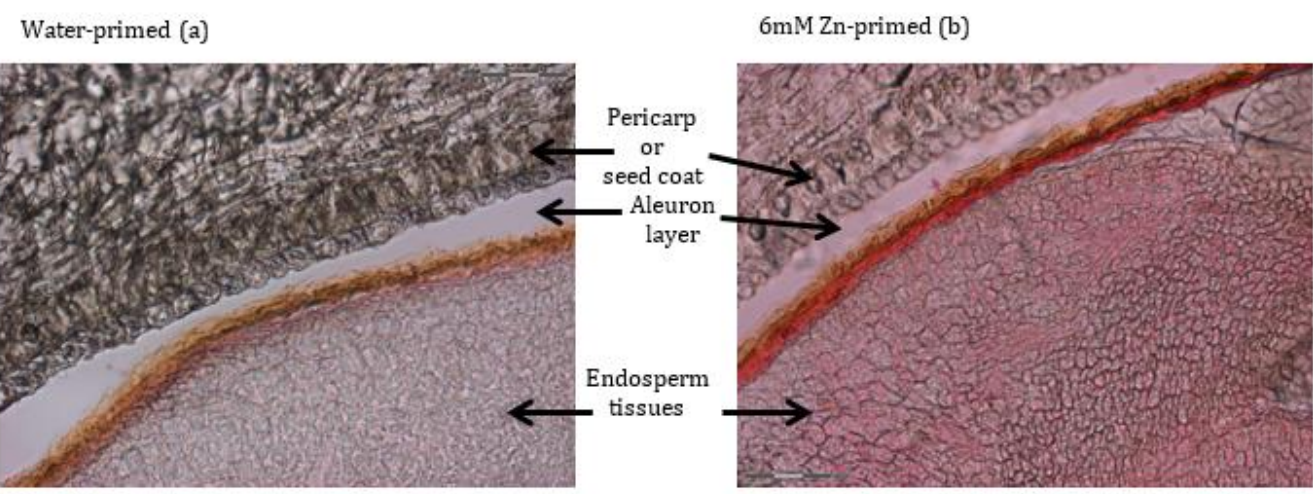

Figure 4. DTZ-staining of $\mathrm{Zn}$ in a spinach seed of water-primed (a) and $\mathrm{Zn}$-primed (b) seedlings with $6 \mathrm{mM} \mathrm{ZnSO}_{4} \cdot 7 \mathrm{H}_{2} \mathrm{O}$. Red staining indicates $\mathrm{Zn}$ localization, especially in the aleurone layer, endosperm, and pericarp.

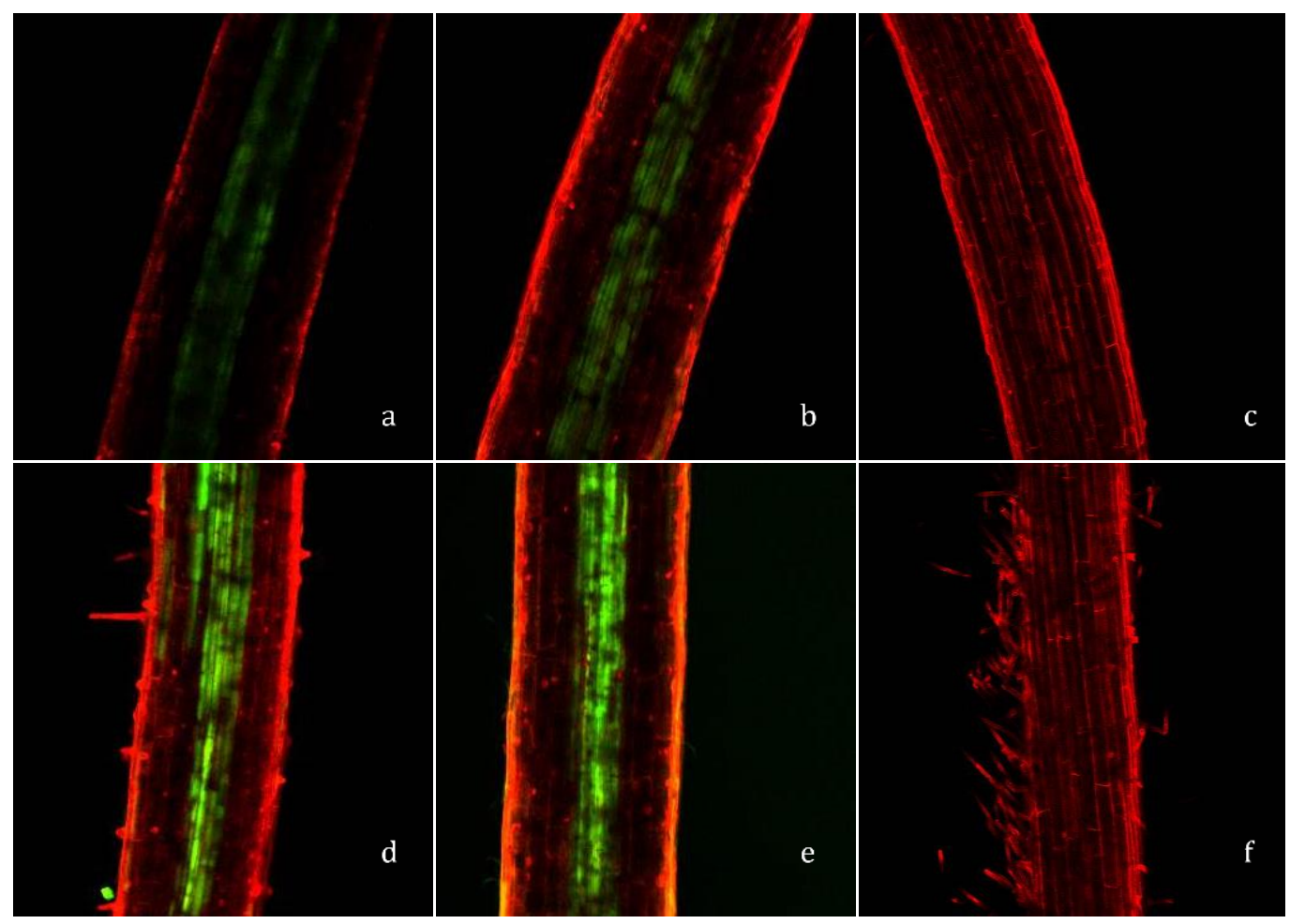

Figure 5. Confocal laser-scanning microscope images of spinach roots of (a) control (unprimed) seedlings, (b) waterprimed seedlings, (d,e) $6 \mathrm{mM}$ and $10 \mathrm{mM}$ Zn-primed seedlings, respectively, and (c,f) seedlings treated with $200 \mu \mathrm{M}$ $\mathrm{N}, \mathrm{N}, \mathrm{N}^{\prime}$,N-tetrakis (2-pyridylmethyl) ethylenediamine (TPEN) for $30 \mathrm{~min}$ and then exposed to $15 \mu \mathrm{M}$ Zinpyr-1 for $5 \mathrm{~h}$.

\subsection{Seed Germination at $15^{\circ} \mathrm{C}$ and $8^{\circ} \mathrm{C}$}

Spinach seeds started germination 3 days after sowing. Figure $6 \mathrm{a}, \mathrm{b}$ represents seed germination at $15^{\circ} \mathrm{C}$ and $8{ }^{\circ} \mathrm{C}$, respectively. At $15^{\circ} \mathrm{C}$, there was no statistical difference for germination speed between water- and $\mathrm{Zn}$-primed seeds, but all priming treatments showed a significant increase in germination compared to unprimed seeds. These differences were diminished after Day 6. At the final count (Figure 6a), Day 14, Zn-priming reflected relatively higher total germination but differences were not significant compared to unprimed and water-primed treatments. 
(a)

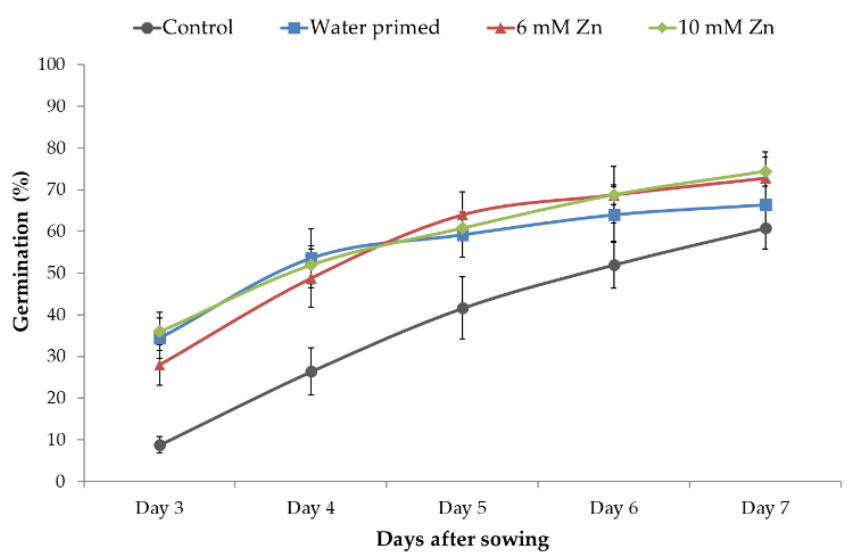

(b)

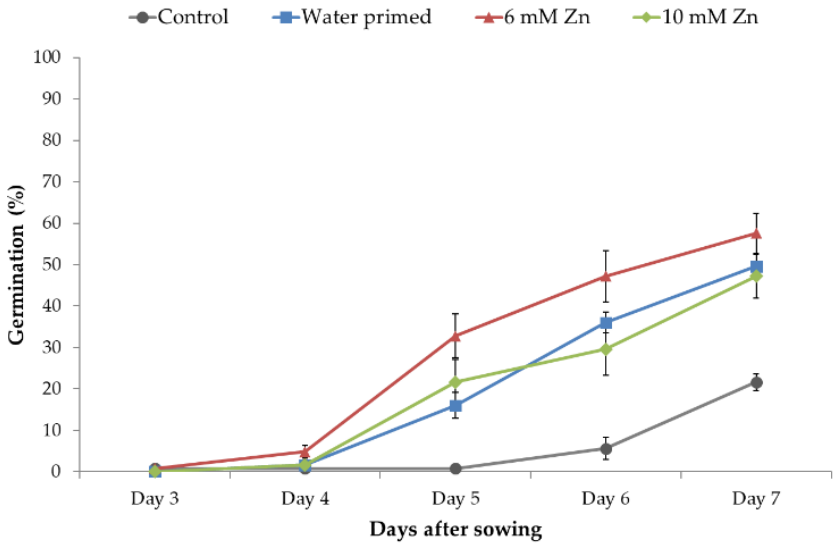

Figure 6. Germination speed of control, water-, $6 \mathrm{mM}$, and $10 \mathrm{mM}$ Zn-primed spinach seeds germinated at $15^{\circ} \mathrm{C}(\mathrm{a})$ and $8^{\circ} \mathrm{C}(\mathbf{b})$ in Petri dishes. Germination was monitored daily up to 7 days after sowing. Data presented are the means of four replicates (25 seeds in each replicate) with standard errors.

At $8{ }^{\circ} \mathrm{C}$, Zn-priming at $6 \mathrm{mM} \mathrm{Zn}$ concentration showed a significantly higher germination speed compared to unprimed, water-, and $10 \mathrm{mM} \mathrm{Zn-priming} \mathrm{treatments} \mathrm{(Figure} \mathrm{6b).}$ However, there was no significant difference in germination speed between water- and $10 \mathrm{mM}$ Zn-priming treatments, but both treatments showed significant increases compared to unprimed seeds. At final count (Figure 7b), $6 \mathrm{mM}$ Zn-priming showed a significant increase in total germination $(>10 \%)$ compared to unprimed and water-primed seeds. There was no significant difference between unprimed, water-, and $10 \mathrm{mM}$ Zn-primed treatments. Final germination recorded on Day 14 showed no significant effect of treatments when seeds were germinated at $15^{\circ} \mathrm{C}$ (Figure 7a); however, at $8{ }^{\circ} \mathrm{C}$, treatment with $6 \mathrm{mM} \mathrm{Zn}$ improved germination (Figure $7 \mathrm{~b}$ ).

(a)

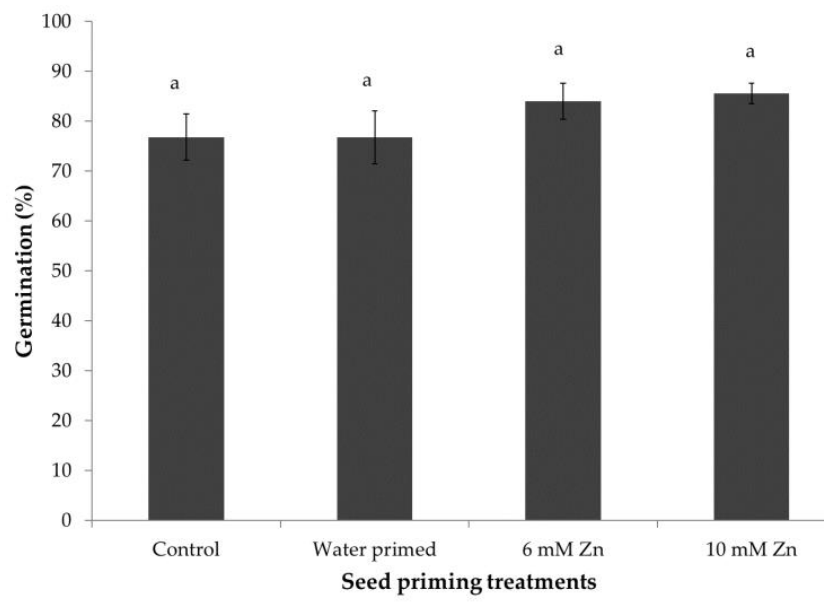

(b)

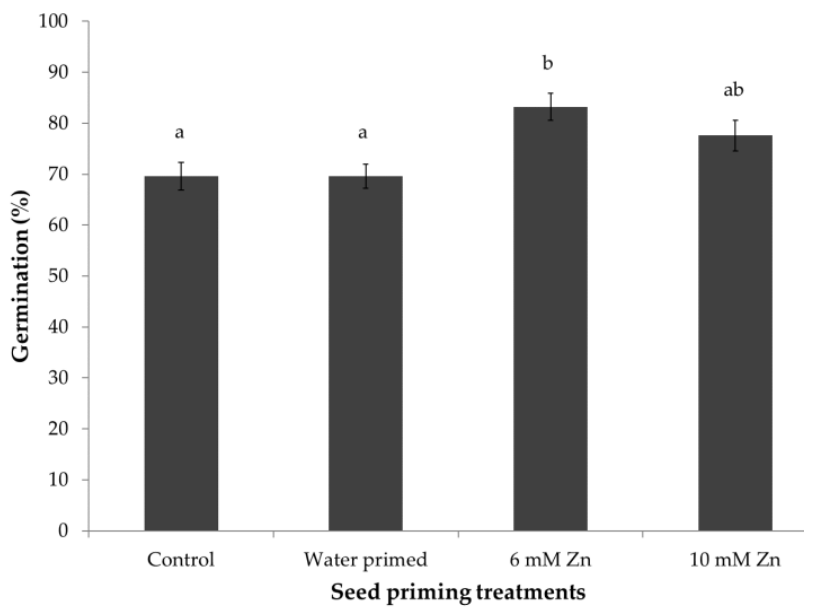

Figure 7. Final germination (\%) of spinach seeds after 14 days of sowing, germinated at $15{ }^{\circ} \mathrm{C}(\mathbf{a})$ and $8{ }^{\circ} \mathrm{C}(\mathbf{b})$ on top of paper in Petri dishes. Seed priming treatments include control (unprimed), water- primed, $6 \mathrm{mM}$, and $10 \mathrm{mM} \mathrm{Zn} \mathrm{in} \mathrm{the}$ priming solution. Bars represent the mean and standard error (SE) of four replicates ( 25 seeds in each replicate). Significant differences between the means were calculated at $p<0.05$ and marked with different alphabets.

\section{Discussion}

Adequate $\mathrm{Zn}$ contents in the seeds are essential for vigorous seedlings and resistance against different abiotic stress factors during germination and the early seedling development stage $[25,26]$. Zn seed priming has been used efficiently in various crops, e.g., 
maize [21,27], barley [28], rice [20], and soybean [29], to improve seed germination and resistance against various abiotic stress factors, such as drought, low root zone temperature, and nutrient deficiencies. However, $\mathrm{Zn}$ seed priming improves germination and seedling development, but determining the optimum concentration of $\mathrm{Zn}$ in the priming solution to attain the beneficial effects of $\mathrm{Zn}$ priming is very important. In the present study, Zn-priming of spinach seeds at $6 \mathrm{mM}$ and $10 \mathrm{mM} \mathrm{Zn}$ concentrations showed the best effects on germination (Figure 1b). However, in the beginning (Figure 1a), Zn-priming at $1 \mathrm{mM} \mathrm{Zn}$ concentration showed significant increase in seed germination compared to unprimed seeds but that effect had disappeared at the final germination count. Previously, Ajouri et al. [28] and Prom-u-Thai et al. [20] also reported similar findings in barley and rice, respectively, where $\mathrm{Zn}$ seed priming showed beneficial effects on seed germination and early seedling development at certain $\mathrm{Zn}$ concentrations. Higher levels of $\mathrm{Zn}$ concentration in the priming solution may exert a toxic effect during the germination process and development of young seedlings. The results in the present study indicate the advantageous role of $\mathrm{Zn}$ seed priming in improving spinach seed germination, in particular during low temperatures. In the current study, final germination recording was performed on Day 14; however, according to International Seed Testing Associsation (ISTA) guidelines [30], final germination in spinach is scored on Day 21. Standard germination tests are performed using either 15 or $10^{\circ} \mathrm{C}$ [30]. Since "low temperature" was chosen as $8^{\circ} \mathrm{C}$ in this experiment, an even slower germination would be expected. This implies that seeds in the current study may not have reached full germination capacity, in particular those tested at low temperature.

Development of red color after staining spinach seeds with DTZ revealed an increase in seed Zn levels after Zn-priming treatment. DTZ is a Zn-chelating agent [31,32], which gives red color after binding with Zn. Additionally, it has been used to determine the localization of $\mathrm{Zn}$ in different organisms and crop seeds, such as algae [33], wheat seeds [22], and rice seeds [20]. In the present study, in the thick and relatively dark colored seed coat of spinach seeds, it was difficult to differentiate the intensity of the red color developed after DTZ staining in water- and Zn-primed seeds with ordinary camera images (Figure 2a-c). Recently, Shrestha et al. [23,34] successfully employed multi-spectral image analysis on tomato seeds to classify varietal differences based on the variation of spectral characteristics in seeds from different varieties. The mean spectrum of multi-spectral images of DTZ-stained seeds after water- and Zn-priming treatments (Figure $2 \mathrm{~d}-\mathrm{f}$ ) showed a clear difference between water- and $\mathrm{Zn}$-primed seeds, but reflectance at each wavelength exhibited a similar trend. The variation in spectra of water- and Zn-primed seeds after DTZ staining can be attributed to increased $\mathrm{Zn}$ in the spinach seeds. Development of red color in the inner parts of Zn-primed seeds (Figure $4 \mathrm{~b}$ ) revealed that primed Zn was not only absorbed in the outer pericarp or seed coat tissues, it was also accumulating in the inner tissues of Zn-primed seeds. Interestingly, Freitas et al. [35] found the highest accumulation of $\mathrm{Zn}$ in the embryo of the $\mathrm{ZnO}$ coated maize seed. This study employed micro-X-ray fluorescence spectrometry and micro-X-ray absorption near-edge spectroscopy for the mapping of $\mathrm{Zn}$ distribution and $\mathrm{Zn}$ speciation analysis.

Translocation of primed $\mathrm{Zn}$ in the young germinating spinach seedlings was determined by using a histochemical technique of $\mathrm{Zn}$ visualization based on the formation of the green-fluorescent complex with Zinpyr- $1\left(\mathrm{C}_{46} \mathrm{H}_{36} \mathrm{Cl}_{2} \mathrm{~N}_{6} \mathrm{O}_{5}\right)$. This technique has been successfully applied in different plant species to detect $\mathrm{Zn}$ in different shoot and root tissues, for example Arabidopsis, [24] Zea mays [36], Noccaea caerulescens, and Thlaspi arvense [37]. As shown in Figure 5a,b, higher intensities of green fluorescence in the roots of $\mathrm{Zn}$-primed seeds indicate active transport of primed $\mathrm{Zn}$ to the young growing roots. Previously, various authors [20,21,29] have also reported the translocation of primed $\mathrm{Zn}$ to the young growing roots during early seedling development, which also supports the seedling growth under $\mathrm{Zn}$-deficient conditions. $\mathrm{Zn}$ is well known for its functions in plants under various biotic and abiotic stress conditions [38]. Our results suggest that active 
translocation of primed $\mathrm{Zn}$ to growing roots can be useful in stress tolerance in spinach grown under various stress conditions.

$\mathrm{Zn}$ is important in the physiological functions, during germination and seedling development [25]. It is vital in the processes of protein synthesis and gene expression. For the structural and functional integrity of biological systems, almost $10 \%$ of proteins require $\mathrm{Zn}$ for their synthesis or functioning [39]. Production of reactive oxygen species (ROS) during seed germination is reported by numerous studies [40-42]. Increased oxidative stress is one of the rapid responses under all kind of stress conditions, including suboptimal or low temperatures. This is associated with increased production of ROS, such as superoxide, hydrogen peroxide, and the hydroxyl radical, involved in membrane damage by lipid peroxidation, protein degradation, enzyme inactivation, and disruption of DNA strands [43]. Micronutrients, such as Zn, are important co-factors of different enzymes involved in the detoxification of ROS, such as superoxide dismutase (SOD) [14,44]. In the present study, compared to unprimed and water-primed seeds, an increase in the germination speed and total germination at $8^{\circ} \mathrm{C}$ by $\mathrm{Zn}$ priming can be attributed to increased $\mathrm{Zn}$ in the seeds. Increased localization of $\mathrm{Zn}$ in the roots of $\mathrm{Zn}$-primed seedlings (Figure 5d,e) also suggested an active role of primed $\mathrm{Zn}$ against the adverse effects of low temperatures during germination, but the current study did not provide any further detail on this potential effect.

Concluding remarks: Previously, beneficial effects of increased seed $\mathrm{Zn}$ levels have shown to improve seed germination and early seedling establishment in stress conditions. This study demonstrates that increased $\mathrm{Zn}$ level of spinach seeds via $\mathrm{Zn}$ priming can enhance seed germination and seedling establishment under low temperature stress conditions. The physiological role of primed $\mathrm{Zn}$ in membrane stability, reduced oxidative stress and performance under field conditions, needs to be further elucidated and studied. Furthermore, the potential of combining $\mathrm{Zn}$ seed priming with agrochemicals, e.g., fungicides, should be evaluated as a tool to reduce pesticide use. Finally, the seed priming technique is simple, cost effective, and can be performed on farms before sowing, e.g., by small-scale farmers.

Author Contributions: Conceptualization, M.I. and B.B.; methodology, M.I.; software, M.I.; validation, M.I.; formal analysis, M.I., G.N. and A.M.; investigation, M.I.; resources, B.B.; data curation, M.I.; writing—original draft preparation, M.I.; writing—review and editing, M.I. and B.B.; visualization, M.I.; supervision, B.B.; project administration, B.B.; funding acquisition, B.B. All authors have read and agreed to the published version of the manuscript.

Funding: This material is based on work that was supported by the Innovation Fund Denmark grant number 110-2012-1, SpectraSeed and GUDP (Grønt Udviklings- og Demonstrationsprogram) grant number 34009-12-0528, and the Danish Agricultural Agency under the Ministry of Environment and Food of Denmark.

Institutional Review Board Statement: Not applicable.

Informed Consent Statement: Not applicable.

Conflicts of Interest: The authors declare no conflict of interest.

\section{References}

1. Ashraf, M.; Foolad, M. Pre-sowing seed treatment-A shotgun approach to improve germination, plant growth, and crop yield under saline and non-saline conditions. Adv. Agron. 2005, 88, 223-271.

2. Powell, A.A.; Matthews, S. The Damaging Effect of Water on Dry Pea Embryos during Imbibition. J. Exp. Bot. 1978, 29, 1215-1229. [CrossRef]

3. Wuebker, E.F.; Mullen, R.E.; Koehler, K. Flooding and Temperature Effects on Soybean Germination. Crop. Sci. 2001, 41, 1857-1861. [CrossRef]

4. Bochicchio, A.; Coradeschi, M.A.; Zienna, P.; Bertolini, M.; Vazzana, C. Imbibitional injury in maize seed independent of chilling temperature. Seed Sci. Res. 1991, 1, 85-90. [CrossRef]

5. Bramlage, W.J.; Leopold, A.C.; Parrish, D.J. Chilling stress to soybeans during imbibition. Plant Physiol. 1978, 61, 525-529. [CrossRef] 
6. Harris, D. On-farm seed priming to accelerate germination in rainfed, dryseeded rice. Int. Rice Res. Notes 1997, $22,1$.

7. Harris, D.; Tripathi, R.; Joshi, A. On-farm seed priming to improve crop establishment and yield in dry direct-seeded rice. In Direct Seeding: Research Strategies and Opportunities; International Research Institute: Manila, Philippines, 2002; pp. 231-240.

8. Chen, K.; Arora, R. Priming memory invokes seed stress-tolerance. Environ. Exp. Bot. 2013, 94, 33-45. [CrossRef]

9. Asher, C. Effects of nutrient concentration in the rhizosphere on plant growth. In Proceedings of the XIIIth Congress International Society of Soil Science's Symposium, Hamburg, Germany, 13 August 1986; Volume 5, pp. 209-216.

10. Genc, Y.; McDonald, G.; Graham, R. The interactive effects of zinc and salt on growth of wheat. In Plant Nutrition for Food Security, Human Health and Environmental Protection; Tsinghua University Press: Beijing, China, 2005; pp. 548-549.

11. Longnecker, N.; Marcar, N.; Graham, R. Increased manganese content of barley seeds can increase grain yield in manganesedeficient conditions. Aust. J. Agric. Res. 1991, 42, 1065-1074. [CrossRef]

12. Rengel, Z.; Graham, R.D. Importance of seed Zn content for wheat growth on Zn-deficient soil. Plant Soil 1995, 173, 259-266. [CrossRef]

13. Graham, R.D.; Rengel, Z. Genotypic Variation in Zinc Uptake and Utilization by Plants. In Zinc in Soils and Plants; Metzler, J.B., Ed.; Springer: Dordrecht, The Netherlands, 1993; pp. 107-118.

14. Cakmak, I. Tansley review no. 111: Possible roles of zinc in protecting plant cells from damage by reactive oxygen species. New Phytol. 2000, 146, 185-205. [CrossRef]

15. Salami, A.U.; Kenefick, D.G. Stimulation of Growth in Zinc-Deficient Corn Seedlings by the Addition of Tryptophan 1. Crop. Sci. 1970, 10, 291-294. [CrossRef]

16. Sekimoto, H.; Hoshi, M.; Nomura, T.; Yokota, T. Zinc Deficiency Affects the Levels of Endogenous Gibberellins in Zea mays L. Plant Cell Physiol. 1997, 38, 1087-1090. [CrossRef]

17. Ashraf, M.; Rauf, H. Inducing salt tolerance in maize (Zea mays L.) through seed priming with chloride salts: Growth and ion transport at early growth stages. Acta Physiol. Plant. 2001, 23, 407-414. [CrossRef]

18. Harris, D.; Rashid, A.; Miraj, G.; Arif, M.; Shah, H. 'On-farm' seed priming with zinc sulphate solution-A cost-effective way to increase the maize yields of resource-poor farmers. Field Crop. Res. 2007, 102, 119-127. [CrossRef]

19. Muhammad, I.; Kolla, M.; Volker, R.; Günter, N. Impact of Nutrient Seed Priming on Germination, Seedling Development, Nutritional Status and Grain Yield of Maize. J. Plant Nutr. 2015, 38, 1803-1821. [CrossRef]

20. Prom-U-Thai, C.; Rerkasem, B.; Yazici, A.; Cakmak, I. Zinc priming promotes seed germination and seedling vigor of rice. J. Plant Nutr. Soil Sci. 2012, 175, 482-488. [CrossRef]

21. Imran, M.; Mahmood, A.; Römheld, V.; Neumann, G. Nutrient seed priming improves seedling development of maize exposed to low root zone temperatures during early growth. Eur. J. Agron. 2013, 49, 141-148. [CrossRef]

22. Ozturk, L.; Yazici, M.A.; Yucel, C.; Torun, A.; Cekic, C.; Bagci, A.; Ozkan, H.; Braun, H.-J.; Sayers, Z.; Cakmak, I. Concentration and localization of zinc during seed development and germination in wheat. Physiol. Plant. 2006, 128, 144-152. [CrossRef]

23. Shrestha, S.; Deleuran, L.C.; Olesen, M.H.; Gislum, R. Use of Multispectral Imaging in Varietal Identification of Tomato. Sensors 2015, 15, 4496-4512. [CrossRef]

24. Sinclair, S.A.; Sherson, S.M.; Jarvis, R.; Camakaris, J.; Cobbett, C.S. The use of the zinc-fluorophore, zinpyr-1, in the study of zinc homeostasis in arabidopsis roots. New Phytol. 2007, 174, 39-45. [CrossRef]

25. Cakmak, I. Enrichment of cereal grains with zinc: Agronomic or genetic biofortification? Plant Soil 2008, 302, 1-17. [CrossRef]

26. Welch, R.M.; Graham, R.D. A new paradigm for world agriculture: Meeting human needs-productive, sustainable, nutritious. Field Crop Res. 1999, 60, 1-10. [CrossRef]

27. Harris, D.; Rashid, A.; Miraj, G.; Arif, M.; Yunas, M. 'On-farm' seed priming with zinc in chickpea and wheat in pakistan. Plant Soil 2008, 306, 3-10. [CrossRef]

28. Ajouri, A.; Asgedom, H.; Becker, M. Seed priming enhances germination and seedling growth of barley under conditions of $\mathrm{P}$ and Zn deficiency. J. Plant Nutr. Soil Sci. 2004, 167, 630-636. [CrossRef]

29. Muhammad, I.; Volker, R.; Günter, N. Accumulation and distribution of Zn and Mn in soybean seeds after nutrient seed priming and its contribution to plant growth under Zn- and Mn-deficient conditions. J. Plant Nutr. 2017, 40, 695-708. [CrossRef]

30. ISTA. The germination test. In International Rules for Seed Testing; International Seed Testing Association: Bassersdorf, Switzerland, 2020; pp. 5-56.

31. McNary, W.F. Zinc-Dithizone Reaction of Pancreatic Islets. J. Histochem. Cytochem. 1954, 2, 185-195. [CrossRef]

32. López-García, C.; Varea, E.; Palop, J.J.; Nacher, J.; Ramirez, C.; Ponsoda, X.; Molowny, A. Cytochemical techniques for zinc and heavy metals localization in nerve cells. Microsc. Res. Tech. 2002, 56, 318-331. [CrossRef]

33. Pawlik-Skowrońska, B. Resistance, accumulation and allocation of zinc in two ecotypes of the green alga Stigeoclonium tenue Kütz. coming from habitats of different heavy metal concentrations. Aquat. Bot. 2003, 75, 189-198. [CrossRef]

34. Shrestha, S.; Deleuran, L.C.; Gislum, R. Classification of different tomato seed cultivars by multispectral visible-near infrared spectroscopy and chemometrics. J. Spectr. Imaging 2016, 5, 9. [CrossRef]

35. Freitas, M.N.; Guerra, M.B.B.; Adame, A.; Moraes, T.F.; Junior, J.L.; Pérez, C.A.; Abdala, D.B.; Cicero, S.M. A first glance at the micro-ZnO coating of maize (Zea mays L.) seeds: A study of the elemental spatial distribution and Zn speciation analysis. J. Anal. At. Spectrom. 2020, 35, 3021-3031. [CrossRef]

36. Seregin, I.V.; Kozhevnikova, A.D. Histochemical methods for detection of heavy metals and strontium in the tissues of higher plants. Russ. J. Plant Physiol. 2011, 58, 721-727. [CrossRef] 
37. Kozhevnikova, A.D.; Erlikh, N.T.; Zhukovskaya, N.V.; Obroucheva, N.V.; Ivanov, V.B.; Belinskaya, A.A.; Khutoryanskaya, M.Y.; Seregin, I.V. Nickel and zinc effects, accumulation and distribution in ruderal plants Lepidium ruderale and Capsella bursapastoris. Acta Physiol. Plant. 2014, 36, 3291-3305. [CrossRef]

38. Marschner, H.; Marschner, P. Marschner's Mineral Nutrition of Higher Plants; Academic Press: Cambridge, MA, USA, 2012.

39. Andreini, C.; Banci, L.; Bertini, I.; Rosato, A. Counting the Zinc-Proteins Encoded in the Human Genome. J. Proteome Res. 2006, 5, 196-201. [CrossRef] [PubMed]

40. Cakmak, I.; Strbac, D.; Marschner, H. Activities of Hydrogen Peroxide-Scavenging Enzymes in Germinating Wheat Seeds. J. Exp. Bot. 1993, 44, 127-132. [CrossRef]

41. Bailly, C.; Bogatek-Leszczynska, R.; Côme, D.; Corbineau, F. Changes in activities of antioxidant enzymes and lipoxygenase during growth of sunflower seedlings from seeds of different vigour. Seed Sci. Res. 2002, 12, 47-55. [CrossRef]

42. Qin, J.; Liu, Q. Oxidative metabolism-related changes during germination of mono maple (Acer mono Maxim.) seeds under seasonal frozen soil. Ecol. Res. 2009, 25, 337-345. [CrossRef]

43. Allen, D.J.; Ort, D.R. Impacts of chilling temperatures on photosynthesis in warm-climate plants. Trends Plant Sci. 2001, 6, 36-42. [CrossRef]

44. Cakmak, I.; Marschner, H. Increase in Membrane Permeability and Exudation in Roots of Zinc Deficient Plants. J. Plant Physiol. 1988, 132, 356-361. [CrossRef] 